\title{
Protests Against Oil Exploration at Sea: Lessons from the Arctic
}

\section{Sunrise Arbitration ${ }^{1}$}

\author{
Joanna Mossop ${ }^{2}$ \\ Law Faculty, Victoria University of Wellington
}

PO Box 600

Wellington 6140

\section{New Zealand}

\begin{abstract}
:
The decision of the Arbitral Tribunal in the Arctic Sunrise case between the Netherlands and Russia offers considerable guidance to coastal States on how to deal with protesters who violate the safety zone of installations under the Law of the Sea Convention. This article considers these lessons and applies them to another recent type of protest: against vessels conducting seismic surveys above the continental shelf. Some countries provide for a non-interference zone around these vessels to prevent protesters from getting close to the survey vessels. Although this was not directly at issue in the Arctic Sunrise case, the Tribunal's jurisprudence gives guidance as to whether these measures by coastal states to prevent interference are consistent with the Law of the Sea Convention.
\end{abstract}

Keywords: protest, installations, due regard, unjustifiable interference, Arctic Sunrise.

\footnotetext{
${ }^{1}$ This is the pre-publication version of an article published in (2016) 31 International Journal of Marine and Coastal Law 60-87.

${ }^{2}$ Senior Lecturer, Victoria University of Wellington. This article is based on research supported by the New Zealand Law Foundation. The author thanks Bevan Marten and the anonymous reviewer for their useful suggestions for improving this article.
} 


\section{Introduction}

States are increasingly encountering resistance from community groups against the development of oil and gas deposits in their off-shore zones. The United States has seen large protests against the exploration of oil deposits around Alaska, including fleets of kayaks attempting to interrupt survey ships from leaving port. ${ }^{3}$ In New Zealand protest vessels have put themselves in the path of survey ships undertaking seismic surveys in order to disrupt their activities. ${ }^{4}$ Russia has also had its oil exploration and exploitation activities disrupted in the Arctic. ${ }^{5}$

It is this latter situation that gave rise to a recent arbitral decision relating to the arrest and detention of a Greenpeace vessel and crew by the Russian Federation. The Arctic Sunrise arbitration was a case brought by the Netherlands, the flag State of the Arctic Sunrise, against Russia under the dispute settlement provisions of the Law of the Sea Convention (LOSC). ${ }^{6}$ Although Russia refused to recognise the jurisdiction of either the International Tribunal for the Law of the Sea (ITLOS) with regard to provisional measures, or the Arbitral Tribunal for the merits, the decisions in this case have raised some important legal issues for States attempting to respond to protests at sea.

\footnotetext{
${ }^{3}$ For example, see Reuters (US Edition), 'Arctic oil rig departs Seattle-area port despite protest' (30 June 2015). Avaliable at http://www.reuters.com/article/2015/06/30/us-usa-shell-arcticidUSKCNOPA10X20150630; accessed 3 September 2015.

${ }^{4}$ New Zealand Press Association, 'Oil Protester Charged by Police' (24 April 2011), available at http://www.nzherald.co.nz/nz/news/article.cfm?c_id=1\&objectid=10721301; accessed 3 September 2015.

5 Steven Lee Myers, 'Russia Seizes Greenpeace Ship and Crew for Investigation' (20 September 2013) New York Times. Avaliable at http://www.nytimes.com/2013/09/21/world/europe/russia-seizesgreenpeace-ship-for-investigation.html?_r=0; accessed 3 September 2015.

${ }^{6}$ United Nations Convention on the Law of the Sea (Montego Bay, 10 December 1982, in force 16 November 1994) 1833 UNTS 396 (LOSC). For the initiation of the dispute, see Ministry of Foreign Affairs of the Kingdom of the Netherlands, 'Notification and Statement of Claim' (4 October 2013). Available at http://www.pcacpa.org/Notification\%20and\%20Statement\%20of\%20Claime134.pdf?fil_id=2531.
} 
The most significant development is that the case has clarified questions about the extent of a coastal State's jurisdiction in relation to activities that interfere with exploration and exploitation activities. The extent of a State's prescriptive jurisdiction and the right to enforce it against a foreign vessel exercising freedoms of navigation has not been directly raised in previous decisions of international courts or tribunals. In addition, the Arbitral Tribunal's decision on the merits has made some useful observations about States' ability to establish warning zones around installations, that State's response to concerns of piracy or terrorism in relation to installations and the right of hot pursuit.

This article outlines the arbitral decision in the Arctic Sunrise case with particular reference to the light it casts on coastal States' jurisdiction over protests against oil exploration and exploitation activities at sea. ${ }^{7}$ It then considers the approach that some States have taken to discourage interference from some protesters, including establishing non-interference zones around vessels undertaking seismic surveys above their continental shelf. The consistency of these measures in light of the Arctic Sunrise case are evaluated. In making this evaluation, the article identifies some factors that States will need to consider in responding to protests at sea.

\section{The Arctic Sunrise facts and the provisional measures order}

The facts giving rise to the dispute began early in the morning on 18 September 2013, when the Greenpeace vessel the Arctic Sunrise launched five rigid hulled inflatable

\footnotetext{
${ }^{7}$ There is a long history of other types of protest at sea, including against nuclear testing (see G Plant, 'Civilian Protest Vessels and the Law of the Sea' (1983) 14 Netherlands Yearbook of International Law 146) and against whaling activities (see R Caddell, 'Regulating the Whale Wars: Freedom of Protest, Navigational Safety and the Law of the Sea in the Polar Regions' (2015) VI Yearbook of Polar Law 497-544; J Mossop 'Opposing Japanese Whaling in the Southern Ocean: The International Law Implications of Opposing Approaches’ (2008) 11 Asia Pacific Journal of Environmental Law 221234.) This article focuses on protest activities beyond the territorial sea directed towards oil and gas exploration.
} 
boats (RHIBs) which entered the safety zone around the Prirazlomnaya, an oil production platform in the Pechora Sea within Russia's EEZ. ${ }^{8}$ Russia had declared a three mile warning zone around the Prirazlomnaya and the Arctic Sunrise largely stayed outside this zone during the following events. ${ }^{9}$ One of the RHIBs was towing a 'survival capsule' and the intention was to climb onto the platform and remain there until the environmentalists' demands were met. ${ }^{10}$ A Russian coastguard vessel, the Ladoga, was also in the vicinity and launched two RHIBs of its own to oppose the protesters.

Despite some confusion, two of the protesters were able to climb onto the platform but soon decided to descend again in the face of water canon spray from the platform. They were intercepted by one of the Lagoda RHIBs and taken to the Lagoda while the Greenpeace RHIBs returned to the Arctic Sunrise. The Lagoda began ordering the Arctic Sunrise to stop to allow an inspection team on board, which the master of the vessel refused. Efforts to board the Arctic Sunrise at this time were unsuccessful and a threat to open fire was not acted on.

A period of time followed in which there was some negotiation and exchange between the Arctic Sunrise and the Lagoda. The Arctic Sunrise moved away for around nine hours in the hope of encouraging the return of the two protesters, then returned to a distance of around four miles from the platform which it proceeded to circle,

\footnotetext{
${ }^{8}$ The following description of facts is based on the Arbitral Tribunal award. See paras 70-139 Arctic Sunrise Arbitration (The Netherlands v Russia) (Award on the Merits, 14 August 2014). Hereafter Arctic Sunrise (Merits). Available at http://www.pcacases.com/web/view/21; accessed 5 September 2015. For an excellent coverage of the facts giving rise to the dispute and the order for provisional measures, see A. Oude Elferink, 'The Arctic Sunrise Incident: A Multi-faceted Law of the Sea Case with a Human Rights Dimension' (2014) 29(2) International Journal of Marine and Coastal Law (IJMCL) 244-289.

${ }^{9}$ The Netherlands argued that the 3 mile zone, within which mariners were warned to exercise caution, was inconsistent with article 60(5) of the LOSC. The Arbitral Tribunal found that this three nautical mile warning zone was not intended to be a safety zone in terms of article 60 of the LOSC. Arctic Sunrise (Merits) paras 203 and 216.

${ }^{10}$ The aim was to remain until Gazprom promised to abandon its plans to drill for oil at Prirazlomnaya or published a credible oil spill response plan. See ibid, para 84 .
} 
shadowed by the Lagoda. In the evening of 19 September the Arctic Sunrise was boarded by Russian officials from a helicopter. The Arctic Sunrise was towed to the port of Murmansk where the crew were detained, initially charged with piracy under the Russian Federation criminal code. The Netherlands, flag State of the Arctic Sunrise, protested the arrest and demanded the immediate release of the vessel and its crew who became known colloquially as the 'Arctic 30'.

Over the next few months, Russia made a number of assertions as to the legal basis for the arrest of the vessel and its crew. It was first argued that the protesters had engaged in piracy. ${ }^{11}$ Russia also argued that it had a reasonable concern that the RHIBs posed a real threat to the Prirazlomnaya including a concern about terrorism. ${ }^{12}$ The charges were changed to hooliganism in late October. ${ }^{13}$ Russia refused all requests from the Netherlands for the release of the Arctic Sunrise and the Arctic 30.

On 4 October 2013, Netherlands instituted arbitral proceedings against Russia under Annex VII to the LOSC. Pending the constitution of the Arbitral Tribunal, the Netherlands brought a request to the International Tribunal for the Law of the Sea (ITLOS) for provisional measures under article 290(5) of the LOSC. ${ }^{14}$ Russia declared that it did not accept the initiation of the arbitration procedure by the Netherlands due to a declaration it had lodged upon ratification of the LOSC that it did not accept compulsory dispute settlement procedures in relation to disputes 'concerning lawenforcement activities in regard to the exercise of sovereign rights or jurisdiction'. ${ }^{15}$

\footnotetext{
${ }^{11}$ Arctic Sunrise (Merits) para 106.

${ }^{12}$ Ibid, para 276.

${ }^{13}$ Ibid, para 124.

${ }^{14}$ International Tribunal for the Law of the Sea, 'Request for the Prescription of Provisional Measures under Article 290, Paragraph 5, of the United Nations Convention on the Law of the Sea' (21 October 2013). Available https://www.itlos.org/fileadmin/itlos/documents/cases/case_no.22/Request_provisional_measures_en_ withtranslations.pdf; accessed 5 September 2015.

${ }^{15}$ Ministry of Foreign Affairs of the Russian Federation, 'Note verbale' (22 October 2013). Available at https://www.itlos.org/fileadmin/itlos/documents/cases/case_no.22/Note_verbale_Russian_Federation_e ng.pdf; accessed 5 September 2015.
} 
Russia maintained this stance throughout the proceedings in ITLOS and the Arbitral Tribunal. It did not appear, nor did it make formal submissions in relation to the case. ${ }^{16}$

The ITLOS issued an order in relation to the request for provisional measures on 22 November $2013 .{ }^{17}$ The ITLOS found that the Russian declaration under article 298 of the LOSC could not exempt this type of dispute and prima facie the Arbitral Tribunal would have jurisdiction over the dispute. ${ }^{18}$ It proceeded to consider the request for provisional measures despite Russia's absence from the proceedings. ${ }^{19}$ It noted the Netherlands' argument that the Russian Federation could only exercise jurisdiction within the safety zone around installations. Outside that area, the Netherlands argued that only the flag State had jurisdiction. This was based on the concept that 'any exceptions to the general rule [of exclusive flag State jurisdiction] over foreign vessels are explicit and cannot be implied' ${ }^{20}$

The ITLOS did not give any indication of its view on this point in the order for provisional measures. However, two judges provided a separate joint opinion

\footnotetext{
16 Oude Elferink (n 8) has speculated that one reason for Russia's failure to appear was that the enforcement agencies appeared to have mishandled the response to the protest and generally were unprepared for the legal issues that came up. See Oude Elferink (n 8), at p. 289.

17 The Arctic Sunrise Case (Kingdom of the Netherlands v Russian Federation) Request for the Prescription of Provisional Measures (22 November 2013). Available at https://www.itlos.org/fileadmin/itlos/documents/cases/case_no.22/Order/C22_Ord_22_11_2013_orig_ Eng.pdf; accessed 5 September 2015.. See R. Churchill, 'Dispute Settlement in the Law of the Sea: Survey for 2013' (2015) 30(1) International Journal for Marine and Coastal Law (IJCML) 1-53, at pp. 14-22.

${ }^{18}$ Arctic Sunrise (Provisional Measures) para 45. For a discussion of the ITLOS's conclusion that the Netherlands had prima facie satisfied the obligation to exchange views with Russia, see José Manuel Cortés Martín, 'Prior Consultations and Jurisdiction at ITLOS' (2014) 13 Law and Practice of International Courts and Tribunals 1-26.

${ }^{19} \mathrm{Ibid}$, paras 49-54. Russia's failure to appear was the first for a dispute under the LOSC. For a discussion of this issue, see R.Caddell, 'Platforms, Protestors and Provisional Measures: The Arctic Sunrise Dispute and Environmental Activism at Sea' in M. Ambrus and R. Wessel (eds), Netherlands Yearbook of International Law 2014 (T.M.C Asser Press, The Hauge, 2015) 359-384; C. Cembrano-Mallari, 'NonAppearance and Compliance in the Context of the UN Convention on the Law of the Sea Dispute Settlement Mechanism' (2014) 88(2) Philippine Law Journal 88. 300-341; D. Guilfoyle and C. Miles 'Provisional Measures and the MC Arctic Sunrise' (2014) 108(2) American Journal of International Law 271-287.

${ }^{20}$ Arctic Sunrise (Provisional Measures) para 63.
} 
essentially adopting the Netherlands' position. Judge Wolfrum and Judge Kelly stated that:

'a coastal State has only limited enforcement jurisdiction in its exclusive economic zone. These are amongst others the competences set out in article $73,110,111,220,221$ and 226 of the Convention. ... As far as enforcement actions in the exclusive economic zone are concerned the enforcement jurisdiction of the coastal State is limited if it is not legitimized by one of the exceptions mentioned above'. ${ }^{21}$

In contrast Judge Golitsyn, in his dissenting opinion, argued that:

Laws and regulations enacted by the coastal State in furtherance of its exclusive jurisdiction under article 60, paragraph 2, of the Convention would be meaningless if the coastal State did not have the authority to ensure their enforcement. Consequently, it follows from article 60, paragraph 2, of the Convention that the coastal State has the right to enforce such laws and regulations governing activities on artificial islands, installations and structures. $^{22}$

Judge Golitsyn went on to conclude that he considered that the Lagoda was exercising the right of hot pursuit of the Arctic Sunrise for violations committed within the safety zone. ${ }^{23}$

The ITLOS ordered that Russia immediately release the Arctic Sunrise and the Arctic 30 upon the posting of a bond of $€ 3,600,000$ by the Netherlands. ${ }^{24}$ Although the order was made on 22 November 2013, Russia did not accept the Tribunal's order.

\footnotetext{
${ }^{21}$ Arctic Sunrise (Provisional Measures) Separate Joint Opinion of Judge Wolfrum and Judge Kelly, paras 12-13.

${ }^{22}$ Arctic Sunrise (Provisional Measures) Dissenting Opinion of Judge Golitsyn, para 23.

${ }^{23}$ Ibid, para 36.

${ }^{24}$ Arctic Sunrise (Provisional Measures), para 105. The Netherlands posted the bond in early December 2013.
} 
Ultimately it was not until late December that the non-Russian crewmembers were allowed to leave Russia. The Arctic Sunrise remained in detention in Murmansk until it was released by Russia in June 2014.

\section{The Arctic Sunrise Arbitration: Merits}

As mentioned above, the Arbitral Tribunal that considered the merits of the case found that it did have jurisdiction and proceeded despite Russia's failure to appear or participate in the arbitration. ${ }^{25}$ Although the Tribunal did not have the advantage of hearing from both parties to the dispute, it did its best to consider the matter objectively. Of interest is the fact that on 7 August 2015, the Russian Federation delivered a letter to the Permanent Court of Arbitration including a position paper prepared by the Russian Ministry of Foreign Affairs. ${ }^{26}$ Russia continued to maintain that it did was not participating in the arbitration. The Tribunal noted that the position paper was not a formal submission, and considered that the relevant issues were fully in the award, which was released on 14 August 2015.

\section{The role of human rights law}

The Arbitral Tribunal confirmed that protest at sea is 'an internationally lawful use of the sea related to the freedom of navigation' and 'necessarily exercised in conjunction

\footnotetext{
${ }^{25}$ Arctic Sunrise (Merits) para 146. The Arbitral Tribunal consisted of Judge Thomas A Mensah (President), Mr Henry Burmester, Professor Alfred HA Soons, Professor Janusz Symonides and Dr Alberto Székely. The decision that the Tribunal had jurisdiction over the dispute, rejecting Russia's argument based on article 298 of the LOSC, was made in a separate award. See Arctic Sunrise (The Netherlands $v$ Russia) Award on Jurisdiction $(26$ November 2014. Available at www.pcacases.com/web/sendAttach/1325; accessed 5 September 2015.

${ }^{26}$ Ibid, para 68. See also Russian Ministry of Foreign Affairs "On Certain Legal Issues Highlighted by the Action of the Arctic Sunrise against Prirazlomnaya Platform". Available at http://en.mid.ru/en/web/guest/foreign_policy/news/lasset_publisher/cKNonkJE02Bw/content/id/1639745; accessed 11 November 2016.
} 
with the freedom of navigation. ${ }^{27}$ The right is based on the human rights of freedom of expression and freedom of assembly found in international human rights instruments including the International Covenant on Civil and Political Rights ${ }^{28}$ and the Universal Declaration of Human Rights. ${ }^{29}$ These rights are also contained in the European Convention on Human Rights and the European courts have a developed jurisprudence about the right to protest, including at sea. ${ }^{30}$ However, the Arbitral Tribunal stated that the right to protest is limited by the law of the sea including the requirement that States must have due regard to the rights and duties of the coastal State in the EEZ, ${ }^{31}$ which includes the right to take certain measures with respect to installations. ${ }^{32}$

Following the Provisional Measures decision, some commentators speculated about the extent to which the ITLOS or an Arbitral Tribunal could consider human rights law as 'other rules of international law not incompatible' with the LOSC under article 293(1) of the LOSC. Guilfoyle and Miles argued that the ITLOS could consider human rights law, but it would have to be necessary to interpreting or applying the LOSC. ${ }^{33}$ As noted by Caddell, there is no guidance in the LOSC on the role of freedom of speech at sea beyond the notion of freedom of navigation. ${ }^{34}$ It was therefore

\footnotetext{
${ }^{27}$ Ibid, para 227. In its position paper (n 26), Russia argued that, as the purpose of the Greenpeace action was to hinder the lawful activities of the coastal state, the actions of the Arctic Sunrise were "incompatible with the freedom of navigation and cannot be regarded as representing the exercise thereof".

${ }^{28}$ International Covenant on Civil and Political Rights (New York, 16 Dember 1966, in force 23 March 1976) 999 UNTS 171, Arts 19 and 21.

${ }^{29}$ United Nations General Assembly, Universal Declaration of Human Rights, 10 December 1948, Arts 19 and 20.

${ }^{30}$ See Oude Elferink (n 8) at pp. 259-270 for a discussion of the European jurisprudence and also domestic decisions. See also T Treves "Human Rights and Law of the Sea" (2010) 28(1) Berkeley Journal of International Law 1-14; J E Roeschke "Eco-terrorism and Piracy on the High Seas: Japanese Whaling and the Rights of Private Groups to Enforce International Conservation Law in Neutral Waters" (2009) 20(1) Villanova Environmental Law Journal 99-137; J. Teulings, 'Peaceful Protests against Whaling on the High Seas - A Human Rights-Based Approach' in C. Symmons (ed) Selected Contemporary Issues in the Law of the Sea (Martinus Nijhoff, Leiden, 2011) 221- 249. It is not the purpose of this article to explore the human rights dimension of protests at sea in depth.

${ }^{31}$ Article 58(2) LOSC, Arctic Sunrise (Merits), para 228.

${ }^{32}$ Article 60 LOSC.

${ }^{33}$ Guilfoyle and Miles (n 19) at p. 285.

${ }^{34}$ Caddell (n 19) 359-384, at p. 379.
} 
appropriate that the Arbitral Tribunal commented about the relationship between freedom of navigation and human rights law. However, it must be noted that the discussion was relatively brief and did not make reference to the role of article 293(1). Arguably, it was not necessary for the Arbitral Tribunal to extensively rely on human rights law in order to decide the issues raised by the Netherlands.

\section{Coastal State jurisdiction in safety zones around installations}

The Arbitral Tribunal recalled that the exclusivity of flag State jurisdiction in the EEZ is subject to some exemptions. ${ }^{35}$ For example, if the vessel was engaged in piracy, the coastal State would be permitted to board it without the permission of the flag State. ${ }^{36}$

However, the alleged commission of the offences of hooliganism and unauthorised entry into a safety zone ... does not provide a basis under international law for boarding a foreign vessel in the EEZ without the consent of the flag State. The boarding, seizure, and detention of a vessel in the EEZ on suspicion of such offences finds a basis under international law only if the requirements of hot pursuit are satisfied. ${ }^{37}$

It must be assumed that the Arbitral Tribunal meant that there is no basis in international law to arrest a vessel for unauthorised entry into a safety zone in the EEZ when the vessel is outside the safety zone and hot pursuit has not been undertaken. This follows from the Tribunal's later conclusion that if Russia had properly undertaken hot pursuit, then it would have been entitled to exercise jurisdiction. In this paragraph, the Arbitral Tribunal confines the exercise of the coastal State's enforcement jurisdiction

\footnotetext{
${ }^{35}$ Arctic Sunrise (Merits), para 231.

${ }^{36}$ Ibid, para 237; article 110 LOSC. The Arbitral Tribunal found that the Arctic Sunrise could not have been engaged in piracy (as alleged by Russia) because the Prirazlomnaya was a fixed platform and not a vessel. See paras 238-239.

${ }^{37}$ Arctic Sunrise (Merits), para 244.
} 
to the area of the safety zone. ${ }^{38}$ This approach is supported by the fact that article 111 of the LOSC explicitly refers to hot pursuit from safety zones around continental shelf installations. ${ }^{39}$ The point is that there would have been no need for inclusion of a reference to safety zones if the enforcement jurisdiction in relation to breaches extended throughout the EEZ or on the continental shelf. Oude Elferink suggests that this is consistent with the fact that article 60 creates special rights for coastal States and it is appropriate that enforcement jurisdiction in relation to violation of safety zones is limited to the safety zones themselves. ${ }^{40}$

The practical result of this finding is that coastal States will need to have coastguard or naval assets in the vicinity of the installation in order to lawfully arrest the vessel while it is in safety zone or to undertake hot pursuit. In the absence of a vessel capable of enforcing the safety zone, coastal States will need to rely on the flag State to follow up any alleged breaches. ${ }^{41}$

Coastal State interests in enforcing of violations of the safety zone is given support by the way the Arbitral Tribunal interpreted article 111 and the requirement for the vessel to be in the safety zone when pursuit commences. In the Arctic Sunrise case, the Tribunal concluded that it was likely that the first stop order was probably given after the last of the protest RHIBs left the safety zone - if only by a matter of minutes. ${ }^{42}$

\footnotetext{
${ }^{38}$ Ibid, para 247.

${ }^{39}$ Oude Elferink (n 8) 244-289, at p. 258.

${ }^{40}$ Ibid, p. 259.

${ }^{41}$ IMO Resolution A.671(16) (19 October 1989) urged flag states to ensure that suitable measures exist to take action against persons responsible for the conduct of any vessel flying their flag which commits an infringement action against a safety zone, and also that the coastal state should be informed of any follow up action. The Annex to that Resolution stated that every coastal state aware of an infringement of the regulations relating to safety zones around offshore installations 'should take action in accordance with international law and, where it considers necessary, notify the flag State of the infringement' together with the relevant information. Paragraph 3. Sebastian tho Pesch regretted the indeterminacy of the Resolution with respect of the permissible actions that can be taken by the coastal state. S. tho Pesch 'Coastal State Jurisdiction around Installations: Safety Zones in the Law of the Sea' (2015) 30(3) International Journal of Marine and Coastal Law (IJMCL) 512-532, at p. 520.

${ }^{42}$ Arctic Sunrise (Merits), para 267.
} 
Although paragraph 1 of article 111 requires that the foreign vessel must be in the relevant area at the time of the dispute, the Tribunal noted that paragraph 4 states that pursuit is not deemed to have commenced unless 'the pursuing ship has satisfied itself by such practicable means as may be available' that the pursued ship is within the area. ${ }^{43}$ The Tribunal took a functional approach to the operation of this aspect of article 111.

[Paragraph 111(4)] suggests that the location of the foreign ship at the time of the first stop order should not be evaluated with the full benefit of hindsight, but rather looked at from the perspective of the pursuing ship. The Tribunal is also conscious that, in the present case, the relevant maritime area within which the foreign ship or its boats must have been located for the commencement of the pursuit - the 500-metre safety zone is small enough that leaving it may have been a matter of only a few minutes. It may therefore be that, given the closeness in time of the first stop order and the departure of the Arctic Sunrise RHIBs from the relevant zone, and the fact that the Lagoda ostensibly began radioing the stop order as soon as it realised that the Arctic Sunrise RHIBs were returning to their ship, the Ladoga should be seen as having 'satisfied itself by such practicable means as [were] available' that the Arctic Sunrise RHIBs were in the correct zone. ${ }^{44}$

In any case, this was not crucial to the Tribunal's finding, because the hot pursuit failed because the pursuit was interrupted due to the delay in arresting the Arctic Sunrise following the RHIBs' incursion into the safety zone. ${ }^{45}$ However, this interpretation of the commencement of hot pursuit may, in future, allow coastal States

\footnotetext{
${ }^{43}$ Ibid, para 268.

${ }^{44}$ Ibid, para 267.

${ }^{45}$ Ibid, para 275.
} 
some minimal leeway in situations where the enforcement activity is ongoing and the stop order is given promptly even if the vessel has already left the safety zone.

It is worth noting that, in its position paper, Russia had argued that it did not need to rely on hot pursuit in order to arrest the Arctic Sunrise. It claimed that because the Arctic Sunrise had interfered with Russia's sovereign rights in respect of resource exploitation, then it was entitled to exercise enforcement jurisdiction against the vessel in the EEZ. ${ }^{46}$ Russia also argued that it would be very difficult for the coastal state to stop offenders while they were still in the safety zone. ${ }^{47}$ Although the Tribunal did not directly respond to this claim, it is clear that Russia's argument is inconsistent with the finding of the Tribunal that hot pursuit is required before a coastal state can exercise enforcement jurisdiction in relation to violations of the safety zone against a foreign vessel outside the safety zone.

\section{Coastal State rights with regard to laws relating to non-living resources}

Some of the most useful parts of the decision are the conclusions that the Arbitral Tribunal draws about the rights of coastal States to enforce laws regarding non-living resources in the EEZ. It should be noted that, having rejected the arguments put forward by Russia in public, the discussion about alternative bases for jurisdiction became more theoretical, or academic. Nevertheless, the Tribunal made a significant contribution to the jurisprudence around coastal State rights.

First, the Tribunal confirmed that coastal States do have the right to enforce their laws relating to non-living resources in the EEZ, although it declined to expand

\footnotetext{
${ }^{46}$ Position paper (n 26) para 11.3.

${ }^{47}$ Ibid, para 12.9.
} 
on the extent of the right. ${ }^{48}$ The Arbitral Tribunal rejected the viewpoint that an enforcement right does not exist because there is no express right in the LOSC to enforce laws in relation to non-living resources. ${ }^{49}$ It noted that during the negotiations for the LOSC, it was proposed that article 73 contain a reference to non-living resources but that this was rejected. ${ }^{50}$ This did not prevent the Tribunal from finding that an enforcement jurisdiction nevertheless exists. The primary argument for an enforcement jurisdiction is based on the 1958 Geneva Convention on the Continental Shelf. ${ }^{51}$ The International Law Commission, in its commentary on the draft Convention, considered that the concept of 'sovereign rights' included jurisdiction 'in connexion with the prevention and punishment of violations of the law'. ${ }^{52}$

This conclusion may, at first glance, seem inconsistent with general structure of the LOSC, which grants exclusive jurisdiction to the flag State in the high seas and EEZ but provides express exceptions to this principle. ${ }^{53}$ Nevertheless, it must be correct. Article 111 supports the argument by providing for hot pursuit regarding violations 'on the continental shelf, including safety zones around continental shelf installations'.54 This implies that there is an enforcement right over the continental shelf that extends beyond safety zones. In addition, the enforcement jurisdiction of a coastal State in relation to the non-living resources of the continental shelf is supported by academic

\footnotetext{
${ }^{48} \mathrm{Ibid}$, para 284. See also para 324, where the Tribunal found that 'A coastal State has the right to take measures to prevent interference with its sovereign rights for the exploration and exploitation of its nonliving resources'.

${ }^{49}$ See the comments by Judges Wolfrum and Kelly (n 16)..

${ }^{50}$ Arctic Sunrise (Merits), para 281.

${ }^{51}$ Convention on the Continental Shelf (Geneva, 29 April 1958, in force 10 June 1964) 499 UNTS 312.

${ }^{52}$ Arctic Sunrise (Merits), para 283. The Tribunal noted that there was no evidence that the Arctic Sunrise had breached any Russian laws in relation to exploration and exploitation activities on non-living resources in the EEZ, apart from the violation in relation to the safety zone. Para 284.

${ }_{53}$ Articles 73, 110, 111, 220, 221 and 226, LOSC. See Arctic Sunrise (Provisional Measures) Separate Opinion of Judge Wolfrum and Judge Kelly, paras 12-13.

${ }^{54}$ Art 111(2), LOSC.
} 
commentary and State practice under the Geneva Convention and the LOSC. ${ }^{55}$ Academics generally agreed that an enforcement right existed under the Geneva Convention although they differed slightly on the limits to that right. ${ }^{56}$ Under the Geneva Convention, some countries provided for a right to enforce domestic laws relating to the continental shelf, including the United States, ${ }^{57}$ Russia $^{58}$ and Australia. ${ }^{59}$ In disputes about sedentary species on the continental shelf in which foreign vessels were arrested by the coastal State, the disputes centred around the correct definition of sedentary species rather than the existence of the enforcement right. ${ }^{60}$

The next significant contribution made by the Tribunal was in relation to the types of protest actions that could be reasonably considered as constituting an interference with the exercise of the coastal State's sovereign rights. The Tribunal considered that it would be reasonable for a coastal State to prevent:

(i) violations of its laws adopted in conformity with the Convention; (ii) dangerous situations that can result in injuries to persons and damage to

\footnotetext{
55 For a more in-depth discussion about enforcement jurisdiction above the continental shelf, see $\mathrm{J}$ Mossop 'Regulating Uses of Marine Biodiversity on the Outer Continental Shelf', in Davor Vidas (ed) Law, Technology and Science for Oceans in Globalisation (Martinus Nijhoff, Leiden, 2010) 319-337, at pp.329-335.

${ }^{56}$ See, for example, E. Brown The Legal Regime of Hydrospace (Stevens \& Sons, London, 1971), at p. 94; S Oda, 'Proposals for Revising the Convention on the Continental Shelf' (1968) 7(1) Columbia Journal of Transnational Law 1-31, at pp. 19-20. Some of the discussion was about whether a right of hot pursuit applied to the waters above the continental shelf: see D O'Connell, The International Law of the Sea: Volume II (Clarendon Press, Oxford, 1984), at p. 1087; N Poulantzas, The Right of Hot Pursuit in International Law (AW Sijthoff, Leiden, 1969), at p. 170.

57 A Rovine, 'Contemporary Practice of the United States Relating to International Law' (1975) 68(4) American Journal of International Law 141-153, at p. 149.

${ }^{58}$ Edict of the Presidium of the USSR Supreme Soviet concerning the Continental Shelf, 6 February 1968, (1968) 7 International Law Materials 392-394, cited in Brown (n 56), p. 93.

${ }^{59}$ L Goldie, 'Australia's Continental Shelf: Legislation and Proclamations' (1954) 3(4) International and Comparative Law Quarterly, 535-575

${ }^{60}$ These disputes included one between Brazil and France over lobsters in 1963 in which Brazil arrested three French vessels: I Azzam, 'The Dispute Between France and Brazil over Lobster Fishing in the Atlantic' (1964) 13(4) International and Comparative Law Quarterly 1453-1459. A second dispute arose between the United States and Canada in 1994 over scallops in which Canada arrested two US vessels: W von Zharen, 'An Ecopolicy Perspective for Sustaining Living Marine Species' (1999) 30(1) Ocean Development \& International Law 1-42, at p. 4; J Van Dyke, 'Modifying the 1982 Law of the Sea Convention: New Initiatives on Governance of High Seas Fisheries Resources: the Straddling Stocks Negotiations' (1995) 10(2) International Journal of Marine \& Coastal Law 219-227, at pp. 221-222.
} 
equipment and installations; (iii) negative environmental consequences ... and (iv) delay or interruption in essential operations. ${ }^{61}$

Third, the Tribunal confirmed that measures taken by the coastal State must be reasonable, necessary, and proportionate. ${ }^{62}$ The right of enforcement must consider the obligation to have due regard for the rights of other States, and so some protest action should be tolerated as long as it does not amount to an interference with the coastal State's sovereign rights. ${ }^{63}$ It may be difficult for coastal States to draw the line between tolerable protest and interference. ${ }^{64}$

Fourth, the Tribunal referred to the requirement in article 78 of the LOSC that the exercise of the coastal State's rights over the continental shelf must not infringe or result in any unjustifiable interference with navigation. ${ }^{65}$ The Tribunal emphasised that the involvement of the Arctic Sunrise in protesting at the oil platform had come to an end at the time of the arrest. ${ }^{66}$ It concluded that, because there was no evidence that at the time of the arrest the Arctic Sunrise was interfering with the operation of the platform, the arrest would have amounted to an unjustifiable interference even if it was conducted pursuant to Russia's rights over the continental shelf. This seems to imply that the arrest must coincide with the breach of the rights and any delay in arresting the vessel might mean that it becomes unjustifiable.

This latter observation imposes a significant limit on the ability of the coastal State to exercise enforcement rights against vessels that have violated its legitimate laws in place to protect its rights over the continental shelf. The Tribunal appears to

\footnotetext{
${ }^{61}$ Arctic Sunrise (Merits), para 327.

${ }^{62}$ Ibid, para 326.

${ }^{63}$ Ibid, para 328.

${ }^{64}$ Some assistance may be derived from the human rights discussions of the right to protest. See (n 30).

${ }^{65}$ Ibid, para 331.

${ }^{66}$ Ibid, para 330.
} 
take the view that the arrest must occur at the time of the violation. The Arctic Sunrise was arrested a day and a half after the protest, but it had returned to the oil platform and was circling it at a distance of four miles. ${ }^{67}$ Although no evidence was presented by Russia, the Tribunal seemed to discount any potential concern that the vessel might resume its protest activity. It is therefore left uncertain whether a coastal State has a right to take measures to prevent breaches of its legitimate regulations unless the vessel is conducting such activity or it is clearly imminent. Such a limitation would be consistent with giving due regard to the rights of the State exercising freedom of navigation.

A final comment worth noting in this context was the Tribunal's conclusion that a coastal State has power 'in its EEZ' to take preventative action where there is a reasonable belief that the vessel might be involved in a terrorist attack on an installation or structure of the coastal State. ${ }^{68}$ This is because a terrorist attack would involve a direct interference with the exercise of the coastal State's rights to explore and exploit the resources of the non-living resources of the seabed. However, the Tribunal declined to consider the extent of this right because there was no evidence that the Arctic Sunrise was engaged or likely to engage in terrorist activities. ${ }^{69}$

There is a significant question as to whether the power to take preventative action in relation to terrorism is limited to the safety zone or whether it applies in the EEZ more broadly. On the one hand, the Arbitral Tribunal was clear that enforcement jurisdiction in relation to violations of the safety zone had to be taken while the vessel was in the safety zone or in course of hot pursuit. Such offences may lead to the endangerment of vessels, personnel or the installation - as would terrorism. However,

\footnotetext{
${ }^{67}$ Ibid, paras 85-100.

${ }^{68}$ Ibid, para 314.

${ }^{69}$ Ibid, p 314.
} 
arguably the potential consequences of a terrorist act are far graver than any usual infringement of the safety zone and may be of such significance that a coastal State should be given room to take enforcement action prior to the suspect vessel entering the safety zone.

Two points support a broader power to take action against suspected terrorist activity targeting installations and structures. First, the wording of the Tribunal's statement was that the right belonged to a coastal State 'in its EEZ'. As mentioned above, the Tribunal had used this language elsewhere in the decision to apparently mean 'the EEZ beyond the safety zone'. ${ }^{70}$ Second, the ability to take preventative action outside the safety zone would be limited by the requirements to act reasonably and not to unjustifiably interfere with the navigation of other States.

\section{Assessment of the Arbitral Tribunal Decision}

Some commentators were critical of the ITLOS decision on provisional measures for either failing to adequately explain its reasoning or its uncritical acceptance of arguments made by the Netherlands. ${ }^{71}$ These failings may in part be attributable to Russia's failure to appear. However, the Arbitral Tribunal demonstrated - as it is required to do - care in assessing the claim objectively. In doing so it has produced a rich source of jurisprudence in relation to coastal State jurisdiction in relation to safety zones around installations. Coastal and flag States will benefit from the Tribunal's conclusions about the extent of coastal State jurisdiction in relation to safety zones but also in relation to non-living resources more generally.

\footnotetext{
70 See above at footnote 37.

${ }^{71}$ E.g. Caddell (n 19) 359-384 and Guilfoyle and Miles (n 19) 271-287; . N. Peiris, 'Arctic Sunrise from ITLOS: The Arctic Surprise and in Search of a Balanced Order' (2015) 29(1) Ocean Yearbook 44-60.
} 
One observation is that the Tribunal often phrased its statements about the rights of coastal States and flag States in terms of the EEZ rather than the continental shelf. This undoubtedly reflects the overlapping nature of the EEZ and continental shelf regimes in the LOSC. However, this raises the question about the applicability of the Tribunal's findings in relation to jurisdiction on the continental shelf beyond 200 nautical miles. More than 80 States may have sovereign rights over areas of their continental shelf that extends beyond the 200 mile EEZ limit. ${ }^{72}$

Part VI of the LOSC states that article 60, in relation to installations, applies mutatis mutandis to the continental shelf. ${ }^{73}$ There is no distinction in Part VI to coastal State rights within, or beyond, 200 nautical miles ${ }^{74}$ beyond a requirement to share some of the proceeds from the exploitation of non-living resources on the extended continental shelf. ${ }^{75}$ Instead, the sovereign rights simply apply to the continental shelf, simpliciter.

In terms of the water column, the question is whether the rights of the flag State are any different above the extended continental shelf, which might affect the jurisdiction that can be exercised by the coastal State in relation to non-living resources. The EEZ is said to be a sui generis regime that applies to the water and the seabed. ${ }^{76}$ All States retain the freedoms of the high seas, including navigation, unless they are incompatible with the rights of the coastal State in the EEZ. ${ }^{77}$ Coastal States and flag

\footnotetext{
${ }^{72}$ At the time of writing, 66 countries have filed one or more submissions with the Commission on the Limits of the Continental Shelf, and a further 14 countries have filed preliminary information with the Commission. See www.un.org/Depts/los.

${ }^{73}$ Article 80, LOSC.

${ }^{74}$ Dispute Concerning Delimitation of the Maritime Boundary between Bangladesh and Myanmar in the Bay of Bengal (Bangladesh/Myanmar) Judgment, 14 March 2012. In this case, at para 361, the ITLOS decided that 'the coastal state exercises sovereign rights over the continental shelf in its entirety without any distinction being made between the shelf within $200 \mathrm{~nm}$ and the shelf beyond that limit'.

75 Article 82, LOSC.

${ }^{76}$ R Churchill and V Lowe, The Law of the Sea ( ${ }^{\text {rd }}$ ed, Manchester University Press, Manchester, 1999) at p.166

77 Article 58(1) and 58(2), LOSC.
} 
States are under a duty to exercise their rights and duties with due regard to the interests of the other. ${ }^{78}$ No similar requirement is contained in Part VI. Instead, it is stated that the rights of the coastal State over the continental shelf do not affect the legal status of the superjacent waters. ${ }^{79}$ The coastal State must not infringe or result in any unjustifiable interference with the navigation and rights and freedoms of other States. ${ }^{80}$

The requirement to refrain from unjustifiable interference with high seas rights and freedoms in article 78 shifts the calculation of rights from a balancing approach (in the EEZ) to a qualified preference for the rights of navigation over coastal State sovereign rights (above the continental shelf). Article 78(2) is clear that some justifiable interference with navigation may be permitted but this will be narrowly interpreted. ${ }^{81}$ The interference must be as minimal as possible and only to the extent necessary for the coastal State to protect its own rights. This suggests that there may be situations in which a coastal State would be expected to exercise restraint if it occurred above the extended continental shelf but less so if it occurred in the EEZ where the other State must have 'due regard' to the interests of the coastal State.

\section{Protests at Sea beyond the Safety Zone}

\footnotetext{
${ }^{78}$ Articles 56(2) and 58(3), LOSC.

${ }^{79}$ Article 78(1), LOSC.

${ }^{80}$ Article 78(2), LOSC.

${ }^{81}$ In relation to the 1958 Continental Shelf Convention (in which article 5(2) was phrased in a similar way to article 78(2) of the LOSC), Young argued that coastal states could impose a ban on trawling over oyster beds because otherwise the rights of the coastal state would be meaningless. R Young 'Sedentary Fisheries and the Convention on the Continental Shelf' (1961) 55(2) American Journal of International Law 359-373, at p. 372. This is consistent with the comments of the ILC in the commentary to the draft articles of the Continental Shelf Convention, where it stated that "Interference, even if substantial, with navigation and fishing might, in some cases, be justified.' 'Report of the International Law Commission to the General Assembly: Covering the work of its Eighth Session' (1956) 2 A/3159, Yearbook of the International Law Commission 253-302, at p 299. Article 78(2) adds the requirement that the coastal state must not 'infringe' on the rights of other states. This underpins the importance of respecting high seas freedoms without removing the acknowledgement that some interference may be justified.
} 
Although the Arbitral Tribunal has gone some way to clarifying coastal States rights in relation to protests aimed at installations, there remains another category of protests posing challenges to coastal States. These are protests against the act of exploring for oil or gas on the continental shelf. Global concern about the potential devastating impact of an accident at a deep-sea oil rig has heightened in the wake of the Deep Water Horizon blowout in the Gulf of Mexico in $2010{ }^{82}$ Concern has centred around the impact of large quantities of oil entering fragile environments such as the Arctic as well as the ability to respond to accidents at remote sites subject to rough weather. Therefore, in some countries civil society organisations have begun to protest the early stages of exploration.

For example, in the United States, environmental organisations have strongly opposed the exploration for oil and gas in the Alaskan waters of the Arctic. In 2015, news that Shell had passed the first hurdle to begin exploratory drilling in the Chukchi Sea prompted protesters in Seattle to take to the water in kayaks to oppose Shell exploration and drilling vessels. ${ }^{83}$ In response, the Coast Guard established temporary safety zones around Shell vessels in Puget Sound and other areas of internal waters or territorial sea. ${ }^{84}$ In Puget Sound, a 'Voluntary First Amendment Area' was established to provide a safe zone for protesters. ${ }^{85}$ As these protests were largely restricted to the

\footnotetext{
82 'Black Storm Rising: The Gulf of Mexico Oil Spill' The Economist 395.8681, 8 May 2010, pp. 69-71; National Commission on the BP Deepwater Horizon Oil Spill and Offshore Drilling, Deep Water: The Gulf Oil Disaster and the Future of Offshore Drilling: Report to the President 2011. Available at http://www.gpo.gov/fdsys/pkg/GPO-OILCOMMISSION/pdf/GPO-OILCOMMISSION.pdf, accessed 1 September 2015.

${ }_{83}$ C Davenport, 'US Will Allow Drilling for Oil in Arctic Ocean' (11 May 2015) New York Times. Available at http://www.nytimes.com/2015/05/12/us/white-house-gives-conditional-approval-for-shellto-drill-in-arctic.html?_r=0, accessed 1 September 2015; BBC News 'Paddle in Seattle Arctic Oil Drilling Protest' (17 May 2015). Available at http://www.bbc.com/news/world-us-canada-32770382, accessed 1 September 2015.

84 A Bailey 'The Protests Continue' (10 May 2015) Petroleum News. Available at http://www.petroleumnews.com/pntruncate/797452878.shtml, accessed 1 September 2015.

${ }^{85}$ Safety Zones and Regulated Navigation Area; Shell Arctic Drilling/Exploration Vessels and Associated Voluntary First Amendment Area, Federal Register 80 (28 April 2015). Available at http://www.gpo.gov/fdsys/pkg/FR-2015-04-28/pdf/2015-09858.pdf, accessed 1 September 2015.
} 
port and territorial waters there is no question that the US was permitted to take such action according to the LOSC.

Other activities have occurred beyond the territorial sea. In New Zealand, a group of protesters targeted the activities of Petrobras' seismic survey ship, Orient Explorer. One of the protesters navigated his fishing vessel ${ }^{86}$ into the path of the Orient Explorer, interrupting the seismic survey which requires the vessel to conduct readings in a straight line. New Zealand dispatched police and naval vessels to keep the protesters away from the Orient Explorer. The protester that had interrupted the survey was arrested and prosecuted under New Zealand legislation. ${ }^{87}$ The protests gathered significant attention, but also caused expense to Petrobras and the New Zealand government. $^{88}$

\section{Responses to protests against survey vessels}

In response to this situation, New Zealand passed an amendment to the Crown Minerals Act 1991 creating new offences under its criminal law. ${ }^{89}$ Two categories of offences have been added. The first is causing damage to or interference with a vessel or structure that is used in mining operations. ${ }^{90}$ The second is more controversial under the law of the sea. The legislation provides for the creation of a non-interference zone around structures ${ }^{91}$ and vessels undertaking prospecting, mining or exploration activity in the territorial sea, the EEZ or above the continental shelf. The zone may extend up to 500

\footnotetext{
${ }^{86}$ The fishing vessel was a New Zealand flagged ship.

${ }^{87}$ Teddy v NZ Police [2014] NZCA 422.

${ }^{88}$ New Zealand's response to the 2011 protests against the Orient Explorer by police and the defence force was estimated to cost NZ\$1.7 million. I Davison, " $\$ 1.7 \mathrm{~m}$ bill for oil protest on high seas" (14 August 2013) New Zealand Herald.

${ }^{89}$ Sections 101A-101C, Crown Minerals Act 2013. Available at www.legislation.govt.nz, accessed 1 September 2015.

${ }^{90}$ Section 101B(1), Crown Minerals Act 2013.

91 'Structures' are defined as meaning any fixed, moveable or floating structure or installation and includes petroleum pipelines, a pumping station, tank station or valve. See section 101A, Crown Minerals Act 1991 (NZ).
} 
metres from the outer edge of the vessel or any attached equipment and be in effect for up to three months. ${ }^{92}$ It is an offence for any vessel or person to enter the noninterference zone 'without reasonable excuse'. ${ }^{93}$ The legislation does not define what is a 'reasonable excuse.' Enforcement officers may stop, board or detain a vessel, remove or arrest a person on board the ship. ${ }^{94}$ The fact that the application of this legislation against foreign vessels may be controversial is reflected in the requirement for the Attorney-General's consent prior to prosecution of a person on board a foreign ship. ${ }^{95}$

New Zealand is not the only government to have passed laws effectively imposing safety zones around moving vessels conducting exploration or exploitation activities for the oil and gas industry. For example, Canada's Collision Regulations create a safety zone around a vessel in Canadian waters 'that is in position for the purpose of exploring or exploiting the non-living natural resources of the sea bed... ${ }^{96}$ The safety zone extends from the outer extremities of the vessel for 500 metres, although a Minister may establish a larger safety zone if it is necessary to ensure navigational safety. No vessel may navigate within a safety zone unless it is supporting the vessel or is in distress. ${ }^{97}$ In South Africa, no vessel may enter a safety zone of 500 metres around an offshore installation, which is defined to include any exploration or production vessel used in prospecting for or the mining of any substance. ${ }^{98}$ The only

\footnotetext{
${ }^{92}$ Section 101B(6) and (7), Crown Minerals Act 1991 (NZ). It seems likely that the 500 metre distance was chosen to echo article 60(5) of the LOSC.

${ }^{93}$ Section 101B(2), Crown Minerals Act 1991 (NZ).

${ }^{94}$ Section 101C(1), Crown Minerals Act 1991 (NZ).

95 Section 101B(9), Crown Minerals Act 1991 (NZ). This requirement appears in other New Zealand legislation where there may be controversy about the application of jurisdiction to a foreign national. For example, see section 6, Antarctica (Environmental Protection) Act 1994 (NZ).

${ }^{96}$ Rule 43(a), Collision Regulations C.R.C., 1978, c. 1416.

${ }^{97}$ Rule 43(c) provides that the restriction on navigation does not apply to a vessel that is: is in distress, is attempting to save life or provide assistance to a vessel in distress, is operated by or on behalf of the state having jurisdiction over the exploration or exploitation operations, or has received permission from the person in charge of the exploration exploitation vessel to enter the safety zone around that vessel.

${ }^{98}$ Sections 1 and 8B, Marine Traffic Act No. 2 of 1981, South Africa.
} 
exceptions are for emergencies or for permitted servicing vessels. The legislation expressly applies to installations above the continental shelf as well as in the EEZ, thus making it applicable to the extended continental shelf. ${ }^{99}$

Any restriction on navigating within 500 metres of a vessel undertaking a seismic survey is not based on any explicit provision in the LOSC. In fact, it is a limitation on a foreign vessel's right of navigation in the EEZ and above the continental shelf akin to that imposed by installations and structures on the continental shelf. Because the right to impose restrictions on navigation around vessels is not a right expressly conferred by the LOSC, the question is whether the legislation is lawful under the LOSC.

The first lesson from the Arctic Sunrise Arbitral Tribunal award is that a coastal State does have the right to take steps to prevent interference with activities aimed at exploring and exploiting the non-living resources of the continental shelf. The Tribunal suggested that it would be reasonable for a coastal State to act to (inter alia) prevent dangerous situations and to prevent delay or interruptions to essential operations. ${ }^{100}$ The absence of any express statements to this effect in the LOSC did not weigh on the Tribunal. Rather, these conclusions flow from the existence of the sovereign right. Thus, coastal States are acting pursuant to legitimate aims in seeking to limit any interference with exploration activities.

The second relevant lesson from the Arbitral Tribunal award is that any action of the coastal State must be reasonable, and must not unjustifiably interfere with the rights of the flag State and the protesters to freedom of navigation. ${ }^{101}$ Due regard to the

\footnotetext{
${ }^{99}$ Section 1, Marine Traffic Act No. 2 of 1981, South Africa.

${ }^{100}$ Arctic Sunrise (Merits) para 327.

${ }^{101}$ Ibid, paras 326 and 331.
} 
rights of the protesters must be given in the EEZ. ${ }^{102}$ Some level of interference may need to be tolerated.

Is a non-interference zone an unjustifiable interference with the freedom of navigation?

Although the Arbitral Tribunal decision in the Arctic Sunrise case confirmed that coastal states may take action to prevent interference by protesters, it did not give guidance as to how the coastal state should decide whether its actions are consistent with the LOSC. The LOSC does provide limited guidance. In the EEZ, the question is whether the coastal state has given 'due regard' to the rights of navigation of the protesters in the EEZ. If the action takes place above the extended continental shelf, the coastal State must not 'unjustifiably interfere' with the rights of navigation. This latter standard may require the coastal State to give more tolerance to protesters but does not prevent the State from taking reasonable and necessary measures to protect its interests. These criteria have caused considerable debate about how they should be implemented in $_{\text {practice. }}{ }^{103}$

Given the circumstances of the arbitration it is perhaps unsurprising that the Arbitral Tribunal did not go into detail as to how a coastal state should decide whether

\footnotetext{
102 Ibid, para 328.

${ }^{103}$ For a discussion of the obligation to have 'due regard', see In the Matter of the Chagos Marine Protected Area Arbitration (Award, 18 March 2015) available at www.pca-cpa.org/MUUK\%2020150318\%20Awardd4b1.pdf?fil_id=2899, accessed 11 November 2015. At paragraph 519, the Tribunal considered that the obligation does not create any universal rule of conduct. The extent of the regard will depend on the nature of the rights of the other State, 'their importance, the extent of the anticipated impairment, the nature and importance of the activities ... and the availability of alternative approaches'. The Tribunal stated that in the majority of cases the assessment will necessarily involve at least some consultation with the rights-holding State. See also M Valencia and K Akimoto 'Guidelines for Navigation and Overflight in the Exclusive Economic Zone' (2006) 30(6) Marine Policy 704-711; R Xiaofeng and C Xizhong 'A Chinese Perspective' (2009) 29 Marine Policy 29(2) 139-146, at p. 145; M Hayashi, 'Military and Intelligence Gathering Activities in the EEZ: Definition of Key Terms' (2005) 29(2) Marine Policy 123-137; B Boczek, 'Peacetime Military Activities in the Exclusive Economic Zone of Third Countries' (1988) 19(6) Ocean Development and International Law 445-468, at p. 455; H Robertson Jr 'Navigation in the Exclusive Economic Zone' (1983) 24 Virginia Journal of International Law 865-915, at p. 882-883.
} 
the imposition of a non-interference zone around vessels is justifiable. In order to fill this gap, the following section suggests a number of factors that should be considered. ${ }^{104}$ These are the same under either the 'due regard' or the 'unjustifiable interference' standards, although in the latter case the coastal State should be very careful before deciding that there is no unjustifiable interference.

First, there must be a real and tangible likelihood that the action of the protest vessel in entering the zone will disrupt the legitimate activities of the vessel. Protesters that pose a nuisance to vessels, for example by getting in their way and requiring them to take longer to get to their destination, would arguably not necessarily disrupt the legitimate purpose of the vessel. Some coastal States may argue that any disruption to the activities of survey ships that increases the cost of exploration is undesirable because of the risk of creating disincentives for oil exploration companies to invest in exploration in the area. However, this sort of annoyance might amount to what the Tribunal described as 'some level of nuisance' that the coastal State would have to tolerate. ${ }^{105}$ On the other hand, protesters that deliberately place themselves in the path of a vessel actively conducting a seismic survey, meaning the vessel must abandon the survey, are directly interfering with the operations of the exploration activity.

The effects of shipping entering the path of a seismic survey can be significant. The survey is carefully designed to build a composite picture of an area of the seafloor by following predetermined grids or tracks over the area. ${ }^{106}$ Interruption of the path of the vessel can cause expensive delays while the vessel aborts the data acquisition and

\footnotetext{
104 These factors were initially described in J Mossop, 'Beyond Delimitation: Interaction between the Outer Continental Shelf and High Seas Regimes' in C Schofield, S Lee and M Kwon (eds) The Limits of Maritime Jurisdiction (Martinus Nijhoff, Leiden, 2014) 753-768.

${ }^{105}$ Arctic Sunrise (Merits) para 328.

${ }^{106}$ International Association of Oil and Gas Producers, An Overview of Marine Seismic Operations April 2011) Report 448, at, p. 7.
} 
returns to repeat the track. ${ }^{107}$ A survey vessel has limited manoeuvrability because of the long streamers housing equipment. ${ }^{108}$ There can be safety concerns if a vessel becomes entangled in the streamers, as well as financial implications for the operator of the vessel. ${ }^{109}$

Second, the relative importance of the interests should be balanced. ${ }^{110}$ Values to be considered may include the economic contribution of the various interests. ${ }^{111}$ Conservation values could be a factor in some circumstances if there is a risk of contamination as a result of the activities. In the case of protests, the fact that the protesters are exercising the freedom of navigation pursuant to the recognised human right to freedom of expression would be important. ${ }^{112}$ The freedom of expression is rarely absolute in domestic legal systems, and is often subject to lawful, proportionate, limitations. ${ }^{113}$ These may include the protection of national security or public order or of public health or morals. ${ }^{114}$ Of course, the protest vessels exercise freedom of navigation but are legally required to observe the rules relating to collision regulations. ${ }^{115}$ Coastal states have an interest in safety of navigation to protect life, the

\footnotetext{
107 Ibid, at p. 42.

${ }^{108}$ Ibid, at p. 12. Streamers can be as long as 12 kilometres long and turning the vessel to run another track can take as long as three hours. See ibid p. 41.

${ }^{109}$ New Zealand Government, Offshore Seismic Surveying, available at http://www.nzpam.govt.nz/cms/iwi-communities/government-role/doc-library/seismic-surveyingfactsheet.pdf, accessed 7 September 2015.

110 This was a factor that the ILC itself identified as part of the 'unjustifiable interference' calculation. See 'Report of the International Law Commission to the General Assembly: Covering the work of its Eighth Session' (1956) 2 A/3159, Yearbook of the International Law Commission, 253-302, at p. 299. ${ }^{111} \mathrm{D}$ Attard The Exclusive Economic Zone in International Law (Clarendon Press, Oxford, 1987), at p. 144; M McDougal and W Burke, The Public Order of the Oceans: A Contemporary International Law of the Sea (New Haven Press, New Haven, 1987), at p. 721.

${ }^{112}$ See, for example, J Teulings, (n 30); D Currie, 'Proposed Amendments to Crown Minerals (Permitting and Crown Land) Bill under International Law' (5 April 2013) available at: http://www.greenpeace.org/new-zealand/en/reports/Legal-opinion-on-the-proposed-Crown-MineralsAct-amendments/, accessed 7 September 2015.

${ }^{113}$ M McMenamin 'Protest at Sea: An Analysis of the Crown Minerals Amendment Act 2013' 8 Human Rights Research Journal (2013), available at http://www.victoria.ac.nz/law/centres/nzcpl/publications/human-rights-researchjournal/publications/vol-8/MATTHEW-MCMENAMIN-HRR-2013.pdf, accessed 7 September 2015. ${ }^{114}$ ICCPR (n 28), Art 19.

115 Caddell (n 19).
} 
environment, and property. Inevitably the considerations involve a balancing of interests between the human rights and the interests of the State. ${ }^{116}$

In the case of regular shipping, freedom of navigation is not an absolute right to take whatever route a master prefers. Vessels already have rules that restrict their navigation when in close proximity to one another. In particular, all vessels must keep out of the way of other vessels restricted in their ability to manoeuvre, which includes vessels engaged in surveys or towing gear. ${ }^{117}$ In practice, survey vessels often use chase vessels to warn other vessels of the hazard posed by the survey vessel and direct them away from the path of the main vessel. Therefore some alteration of the course of the third party vessel may be necessary in the normal course of navigation on the high seas. If the ship has early warning of the survey vessel's presence the necessary evasive action could be factored in and cause little delay to the navigating vessel. However, the creation of a non-interference zone around a vessel and its streamers could add a considerable detour for some vessels.

The coastal State has an interest in ensuring that it is able to exercise its sovereign rights to explore and exploit the non-living resources of the continental shelf. As mentioned above, the coastal State may be concerned that protest against survey operations might deter companies from seeking to explore for resources in that country's continental shelf. In this case, both interests are of considerable weight but the coastal State interest in facilitating the unimpeded exploration of the shelf probably outweighs the protester's rights to express their views by getting in the path of the vessel. They are still able to protest without disrupting the survey.

\footnotetext{
116 Teulings (n 30) discusses a range of international and national court decisions on non-violent protests at sea. See also Oude Elferink (n 6).

117 Convention on the International Regulations for Preventing Collisions at Sea (London, 10 October 1972, entry into force 15 July 1977) 1050 UNTS 18 (COLREGs), rule 18.
} 
Third, the coastal State must ask whether the proposed interference with the high seas rights is as minimal as possible to achieve the coastal State's objectives, or whether a less restrictive option available. If there is a less restrictive method of achieving the coastal State's goals it is arguable that the more restrictive approach will be unjustifiable. One argument is that the coastal State should not impose greater restrictions than that available under international law. Therefore, the coastal State could choose to only respond to breaches of the ColRegs, or the Convention for the Suppression of Unlawful Acts that Endanger the Safety of Navigation. ${ }^{118}$ However, as set out above, this may not achieve the aim of the coastal State, which is to minimise the interference of other vessels with the seismic survey.

The question therefore is whether the attempted regulation is as minimal as possible. For example, is it possible to impose a smaller exclusion zone around the survey vessel, one that would still protect the safety and navigation interests of the survey vessel, while also allowing for greater freedom of navigation? It should be noted that, under the New Zealand legislation, the exclusion zone may be up to 500 metres, allowing for some discretion on the part of the Minister. ${ }^{119}$ This allows for a smaller zone to be declared if that would be possible. However, in practice the non-interference zone is usually set at 500 metres in New Zealand. The South African legislation also provides for a smaller safety zone if the Minister so decides. In contrast, 500 metres has been criticised as being insufficient to protect installations from navigational collisions or terrorist attacks. There were concerns about this during the negotiation of article 60 , but it was decided to leave the distance at 500 metres but allowing for law making by

\footnotetext{
${ }^{118}$ Convention for the Suppression of Unlawful Acts of Violence Against the Safety of Maritime Navigation (SUA) (Rome, 10 March 1988, entered into force 1 March 1992) 1678 UNTS 221. ${ }^{119}$ Sections 101B(7) and (8), Crown Minerals Act 1991 (NZ).
} 
international organisations. ${ }^{120}$ Some discussion has been held in the IMO but there has been no decision that there is a need to extend the existing 500 metre zone. ${ }^{121}$ The general concern is that 500 meters is insufficient to prevent intentional attacks on installations. A vessel approaching at a speed of 25 knots would pass from the outer edge of a safety zone to the installation in approximately 39 seconds. ${ }^{122}$ If vessels are moving towards each other, the time would be lessened, leaving little time for evasive manoeuvring Therefore, it is arguable that 500 metres is reasonable distance to protect the safety of navigation around survey vessels.

Another consideration is whether there is any allowance for inadvertent or necessary entry into the safety zone. Both South Africa and Canada provide exceptions when a vessel is in a distress or responding to an emergency. However, no allowance is made for situations where a vessel enters the zone through error or ignorance. New Zealand's legislation is more vaguely worded: entry into the zone is not permitted unless the vessel has a 'reasonable excuse' which is not defined. It is arguable that New Zealand's legislation could be interpreted to cover inadvertent entry into the zone as an incident of ordinary navigation: so far no judicial interpretation has cast light on this wording.

Finally, the coastal State should consider any guidance that may exist at a regional or international level that would cast light on whether its actions would be unjustifiable. The International Maritime Organisation issued a resolution on 'Assuring

\footnotetext{
${ }^{120}$ D O'Connell, The International Law of the Sea: Volume I (Oxford University Press, Oxford, 1983), at $\mathrm{p} 502$.

${ }^{121}$ A Harel 'Preventing Terrorist Attacks on Offshore Platforms: Do States Have Sufficient Legal Tools?' (2012) 4 Harvard National Security Journal 131-184, at p. 149. For an analysis of the effect of increased concern about terrorism on maritime direct action protest see Glen Plant "International Law and Direct Action Protests at Sea: Twenty Years On (2002) 33 Netherlands Yearbook of International Law 75-117.

${ }^{122}$ S Kaye 'International Measures to Protect Oil Platforms, Pipelines, and Submarine Cables from Attack' (2006-7) 31 Tulane Maritime Law Journal 377-424, at p. 405. Of course, modern warfare technology can pose a threat to a maritime target from a considerable distance, so the 500 metre zone may not be sufficient as a defence against an organised terrorist attack.
} 
Safety During Demonstrations, Protests or Confrontations on the High Seas' in $2010 .{ }^{123}$ While this was primarily in response to the actions of Sea Shepherd against Japanese whaling vessels in the Southern Ocean and applies to the high seas with no reference to the continental shelf, it does assist in the present case. The Resolution called on governments to urge persons under their jurisdiction to refrain from actions that intentionally imperil human life, the marine environment or property during demonstrations, protests, or confrontations at sea. Governments should take action over any breaches of international collision or other applicable regulations ${ }^{124}$ and cooperate to address any such action. Although this resolution did not address the particular situation addressed by the non-interference zones, it reinforces the importance of protecting safety during protests. There is a real danger that protesters deliberately getting in the path of a vessel underway will put safety of life and property at risk.

Overall, a vessel underway is a very different beast from an installation which is fixed and which can be noted on charts. The question is whether requiring vessels to remain 500 metres from a moving survey vessel is an unjustifiable interference with the freedom of navigation, which includes the freedom to protest. Given that protest vessels must comply with the law of the sea, including collision regulations, it does not seem unreasonable to require them to keep their distance from a vessel conducting a seismic survey. The use of chase vessels should help to prevent inadvertent breaches by the usual commercial traffic.

As with any balancing of interests, how reasonable the action is will depend on the circumstances. For example, if the seismic survey is being conducted in areas of

\footnotetext{
${ }^{123}$ Resolution MSC 303.87 (17 May 2010). Available at http://www.maritimenz.govt.nz/adygil/imoresolution.pdf, accessed 5 September 2015.

${ }^{124}$ Including breaches of the SUA Convention.
} 
heavy shipping it may be unreasonable to impose a 500 metre zone. In more isolated waters this may not be such an issue.

\section{Enforcement of non-interference zones}

A final consideration is whether the coastal State may exercise enforcement jurisdiction over protest vessels that breach the non-interference zone. According to the Arctic Sunrise Arbitral Tribunal award, enforcement jurisdiction is part of the sovereign rights the coastal State has in relation to the non-living resources of the seabed. However, this must be exercised reasonably, in light of international law and must not be an unjustifiable interference with the freedom of navigation.

In the case of a non-interference zone, it is arguable that a coastal State may take action to prevent or punish breaches of the zone while that breach is underway. However, the Arbitral Tribunal noted that Russia was not able to arrest the Arctic Sunrise at a later date when it was not threatening to violate the safety zone. ${ }^{125}$ This implies that a coastal State may not be able to arrest a foreign vessel when it is no longer posing a threat to the navigation of the survey vessel. In that case, the coastal State will need to rely on communicating the information about the breach to the flag State, for it to take appropriate action against the vessel. This may not be seen as an effective option for coastal States, as it depends on the flag State taking action against the vessel. In some cases, it seems that flag states may be reluctant to respond to complaints by a coastal State. ${ }^{126}$ However, it is necessitated by the balancing of the interests of the coastal State and the flag State.

\footnotetext{
${ }^{125}$ Arctic Sunrise (Merits) para 331.

${ }^{126}$ Oude Elferink describes some protest action by Greenpeace where the Netherlands failed to respond to complaints about breaches of safety zones by Russia. See Oude Elferink (n 8), at p. 247. See also the Russian Position Paper, above (n 26) at para 13.6.
} 


\section{Conclusion}

As the exploration for resources moves off shore into deeper waters, and the debate about its impact on the environment continues, it is perhaps not surprising that coastal States are struggling to deal with new forms of protest at sea. Russia, despite having advance notice of the Greenpeace protest at Prirazlomnaya found itself on the back foot against protesters determined to climb the installation for publicity purposes. In attempting to take a hard line against the activists, it violated international law in the process, according to the Arbitral Tribunal constituted under the LOSC dispute resolution protest. It is highly regretful that Russia chose to ignore the proceedings as it lost an opportunity to put its version of the events to the Tribunal. However, regardless, the Tribunal issued a thoughtful opinion that cast light on the rights of coastal States. It confirmed that coastal States can take action in certain circumstances to take measures against protests that interfere with essential oil and gas operations, that pose a risk to safety or have serious environmental consequences. ${ }^{127}$ It also confirmed that, despite the absence of any express provision in the LOSC, a coastal State can exercise enforcement jurisdiction against vessels breaching its legitimate regulations. The Tribunal was careful to note that the right to protest at sea was a legitimate exercise of the freedom of navigation and so States needed to be tolerant of some minor nuisance. $^{128}$

Other States are also facing difficulties with protests at sea, including those targeting vessels undertaking seismic surveys. It is unlikely that the negotiators of the LOSC would have anticipated such activities and so no express provision for such activity is found in the Convention. As with other unregulated activities under the

\footnotetext{
${ }^{127}$ Arctic Sunrise (Merits), para 327.

${ }^{128}$ Ibid, para 328.
} 
LOSC, States must turn to the obligations to have 'due regard' for each other's rights and the stipulation that coastal States must not infringe or unjustifiably interfere' with high seas freedoms. Of course, these provisions are open to interpretation, and have caused considerable debate among States as to how they apply in other contexts. What one State considers reasonable, another may consider unreasonable. In order to attempt to impose some framework around this issue, this article has suggested four factors that should be evaluated when considering whether a coastal State measure is justifiable or not. These are: whether the navigation is likely to interfere with the rights of the coastal State to exploit its natural resources; what the strength of the relevant interests is; whether the coastal State measure is as minimal as possible; and what guidelines are available from relevant regional and international organisations.

The Arctic Sunrise arbitration has confirmed that coastal state rights are not restricted to the express rights in the LOSC, but may extend to taking reasonable steps to protect their sovereign rights. There is bound to be disagreement, but this article suggests that a restriction on protest vessels entering a non-interference zone around a survey vessel conducting a seismic survey is potentially justifiable under the LOSC. This will partly depend on the circumstances including the location of the survey vessel, the use of chase boats to warn other vessels in the area, due publication of the zone as well as the general location of the survey vessel in notices to mariners, and how the coastal State provides for inadvertent entry into the zone. Although a coastal State could take enforcement action against foreign ships, this would need to be done reasonably, and at the time of the threatened or actual entry into the non-interference zone. The freedom of navigation is not absolute in the law of the sea and protest vessels owe obligations towards other vessels as do all users of the oceans. 